\title{
Erratum to femoral artery cannulation as a safe alternative for aortic dissection arch repair in the era of axillary artery cannulation
}

\author{
Editorial Office \\ Journal of Thoracic Disease \\ Correspondence to: Editorial Office. Journal of Thoracic Disease. Email: jtd@amepc.org.
}

Submitted Jun 21, 2021. Accepted for publication Jul 02, 2021.

doi: 10.21037/jtd-2021-34

View this article at: https://dx.doi.org/10.21037/jtd-2021-34

Erratum to: J Thorac Dis 2021;13:671-80

In the article that appeared on Page: 671-680, Vol 13, No 2 (February 2021) Issue of the fournal of Thoracic Disease (FTD) (1), the grant number in funding information was published with an error. The funding statement in Acknowledgment section should have been

Funding: This work was supported by the National Natural Science Foundation of China (81500183 to GT), the Guangdong Project of Science and Technology (2017A070701013 to TS) and the Guangzhou Project of Science and Technology (202002020037 to TS).

Instead of

Funding: This work was supported by the National Natural Science Foundation of China (81500183 to GT), the Guangdong Project of Science and Technology (2017A070701013 to TS) and the Guangzhou Project of Science and Technology (202002020023 to TS).

The authors apologize for this error.

Click here to view the updated version of the article.

Open Access Statement: This is an Open Access article distributed in accordance with the Creative Commons AttributionNonCommercial-NoDerivs 4.0 International License (CC BY-NC-ND 4.0), which permits the non-commercial replication and distribution of the article with the strict proviso that no changes or edits are made and the original work is properly cited (including links to both the formal publication through the relevant DOI and the license). See: https://creativecommons.org/ licenses/by-nc-nd/4.0/.

\section{References}

1. Tong G, Zhuang DL, Sun ZC, et al. Femoral artery cannulation as a safe alternative for aortic dissection arch repair in the era of axillary artery cannulation. J Thorac Dis 2021;13:671-80.

Cite this article as: Editorial Office. Erratum to femoral artery cannulation as a safe alternative for aortic dissection arch repair in the era of axillary artery cannulation. J Thorac Dis 2021;13(8):5362. doi: 10.21037/jtd-2021-34 